variables, including post-deposition forming gas anneal (FGA) temperature are listed in the table.

Table 1. Parameters used for the Silicon-Nitride and Silicon-Oxide Main-Effects Experiments

\begin{tabular}{|l|c|c|}
\hline Parameter [units] & $\begin{array}{c}\text { Min } \\
\text { Value }\end{array}$ & $\begin{array}{c}\text { Max } \\
\text { Value }\end{array}$ \\
\hline Hydrogen plasma pre-clean time [min] & 0 & 10 \\
\hline Substrate temp. during deposition [ ${ }^{\circ} \mathrm{C}$ ] & 250 & 300 \\
\hline Silane/ammonia flow ratio [sccm/sccm] & 10 & 16 \\
\hline Ammonia flow rate [sccm] & 19 & 56 \\
\hline Silane/ $\mathrm{N}_{2} \mathrm{O}$ flow ratio [sccm/sccm] & 0.87 & 1.62 \\
\hline Nitrous Oxide flow rate [sccm] & 138 & 553 \\
\hline Diluent nitrogen flow rate [sccm] & 0 & 300 \\
\hline H2 flow rate during deposition [sccm] $_{2}$ ] & 0 & 404 \\
\hline RF-power applied to plasma (nitride) [W] & 47 & 83 \\
\hline RF-power applied to plasma (oxide) [W] & 47 & 70 \\
\hline Temp. of post-deposition $\mathrm{FGA}\left[{ }^{\circ} \mathrm{C}\right.$ ] & 350 & 400 \\
\hline
\end{tabular}

The results of the main-effects experiments in Figs. 1 and 2 show that the emitter surface passivation provided by either PECVD oxides or nitrides can range from almost as poor as a bare or $\mathrm{TiO}_{2}$-covered silicon surface to almost as good as the best thermal-oxide-passivated surface. Unpassivated $\mathrm{TiO}_{2}$-covered cells are typical of those from the commercial Si-PV industry.

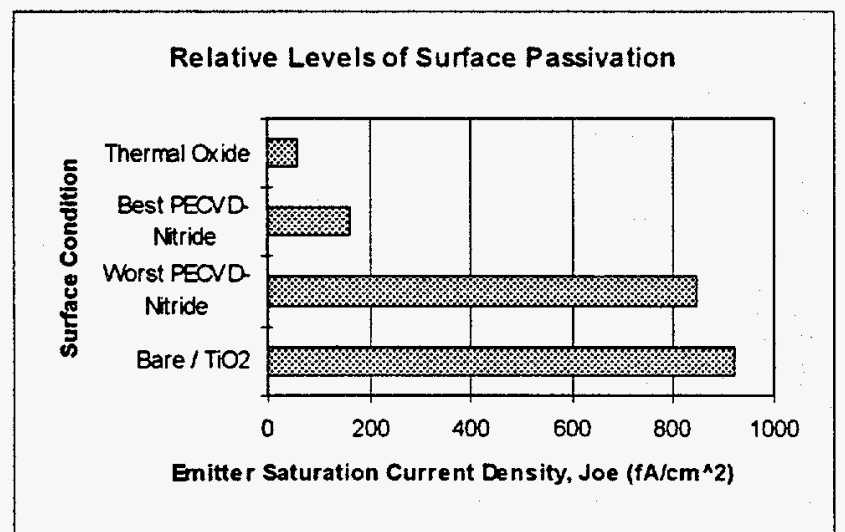

Figure 1. Range of $J_{o e}$ values obtained in the nitride main-effects experiment, measured at $25^{\circ} \mathrm{C}$.

The results of the main-effects experiments showed that the FGA temperature had the largest effect on $J_{\text {oe }}$ for both oxides and nitrides, with the lower temperature being strongly preferred. The higher deposition temperatures produced better passivation for both film types. Interestingly, the hydrogen-plasma pre-clean resulted in higher $J_{\infty e}$ values for both films, possibly because of damage to the surfaces of the float-zone wafers used. This effect may be outweighed by beneficial passivation of bulk defects when this factor is studied on mc-Si cells.

The other factors had smaller, but significant effects, such as the RF-power, where lower power was preferred
Relative Levels of Surface Passivation

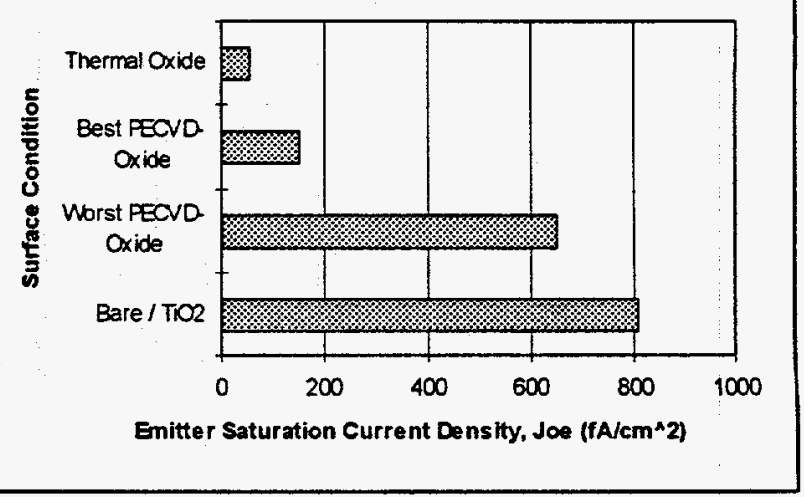

Figure 2. Range of $J_{o e}$ values obtained in the oxide maineffects experiment, measured at $25^{\circ} \mathrm{C}$.

for the nitrides, but higher power for the oxides. In the case of the nitrides, the gas ratios and rates were significant, but for the oxides, they were not. This may be because the oxide always tends to be deposited as $\mathrm{SiO}_{2}$ with a fixed refractive index of 1.5, while the stoichiometric ratio and refractive index for the nitride is a function of the gas rates. The addition of hydrogen during the deposition resulted in slightly higher $J_{\text {oe }}$ values for the nitrides, but slightly lower values for the oxides.

We used this information to plan the quadratic experiments that followed. In order to keep the number of trials to a manageable level, we restricted the factors used to the four that had the largest effect on $\mathrm{J}_{o e}$, and eliminated the detrimental hydrogen pre-cleans.

\section{Quadratic Experiments}

We first performed the oxide quadratic experiment using parameters similar to those in Table 1 , except with the lower limit of the FGA temperature set to $300^{\circ} \mathrm{C}$, since the lower temperature was so strongly preferred earlier. The $\mathrm{SiH}_{4} / \mathrm{N}_{2} \mathrm{O}$ ratio was set to 0.5 and the $\mathrm{N}_{2} \mathrm{O}$ rate was set to $400 \mathrm{sccm}$. We used a statistical analysis program to calculate the functional dependence of $J_{o e}$ on the four factors varied, assuming a dependence of the form:

$$
J_{\infty e}=b_{0}+\sum b_{i} x_{i}+\sum b_{i j} x_{i} x_{j}+\sum b_{i i} x_{i}^{2} \text {, for } i=1 \text { to } 4, j>i
$$

The result of this calculation is shown in a contour plot of the response surface in Fig. 3 . Figure 4 shows the lowest and highest measured values of $J_{0 e}$ from the best and worst trials, respectively, the measured thermally oxidized and bare wafer extreme values, and compares these with the program's predicted optimized value. The optimized PECVD-oxide is still not as good as the thermal oxide.

Because the lowest FGA temperature was so strongly preferred, we chose to fix the FGA temperature at $300^{\circ} \mathrm{C}$ for the nitride quadratic experiment. The diluent nitrogen and hydrogen flow rates were both set to zero. The 


\section{DISCLAIMER}

This report was prepared as an account of work sponsored by an agency of the United States Government. Neither the United States Government nor any agency thereof, nor any of their employees, makes any warranty, express or implied, or assumes any legal liability or responsibility for the accuracy, completeness, or usefulness of any information, apparatus, product, or process disclosed, or represents that its use would not infringe privately owned rights. Reference herein to any specific commercial product, process, or service by trade name, trademark, manufacturer; or otherwise does not necessarily constitute or imply its endorsement, recommendation, or favoring by the United States Government or any agency thereof. The views and opinions of authors expressed herein do not necessarily state or reflect those of the United States Government or any agency thereof. 


\section{DISCLAIMER}

Portions of this document may be illegible in electronic image products. Images are produced from the best available original document. 
contour plots for both $J_{o e}$ and refractive index of the nitride films are shown in Figures 5 and 6.

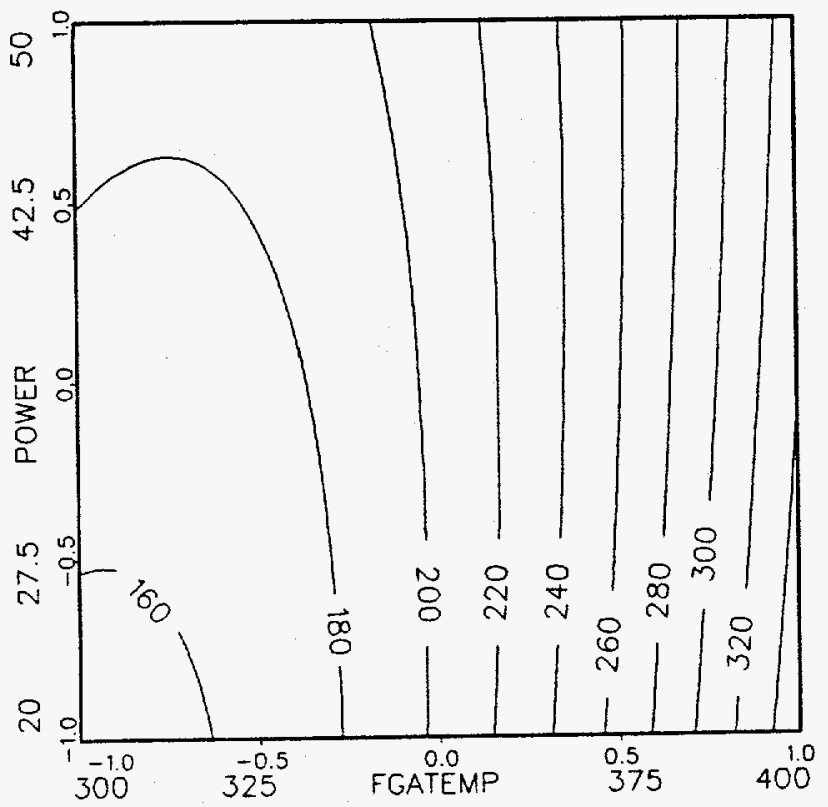

Figure 3. Contours of constant $J_{o e}\left[f A / \mathrm{cm}^{2}\right]$ for PECVDoxide films on the response surface, which predicts a minimum value in the lower left corner.

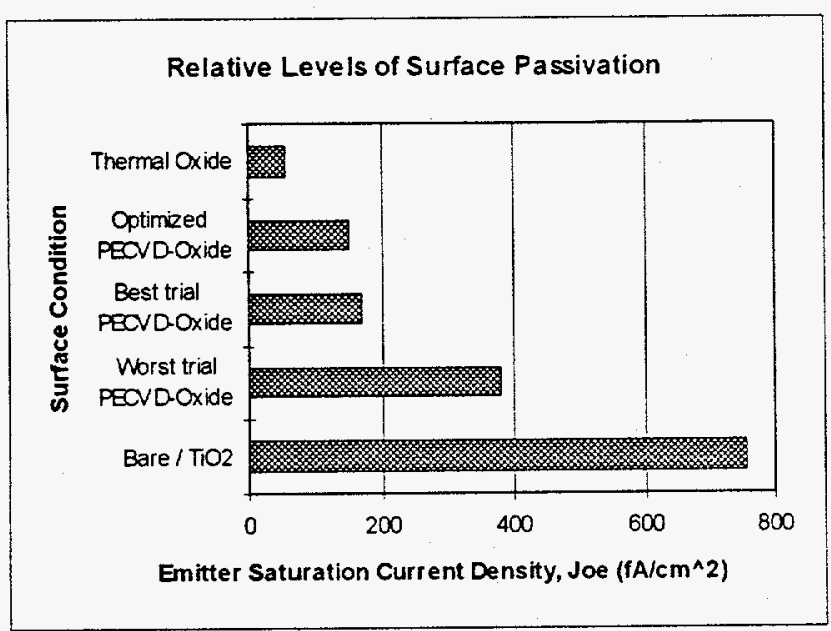

Figure 4. The measured and predicted $J_{0 e}$ values for the oxide quadratic experiment.

The analysis predicted that deposition conditions existed where both the emitter recombination could be minimized and the refractive index could be maximized at a value of 2.3, which is optimum for a single-layer AR coating on a Si cell encapsulated under glass.

Figure 7 shows the measured values of $J_{0 e}$ from the best and worst trials, the measured thermally oxidized and bare wafer values, and the predicted optimized value.

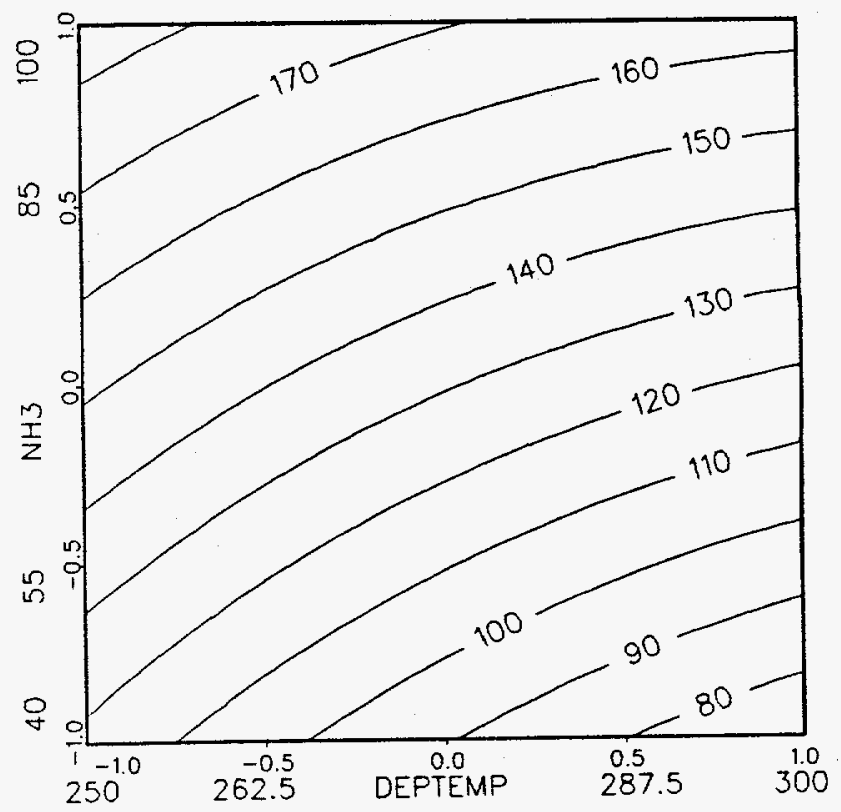

Figure 5. Contours of constant $J_{0 e}\left[f A / \mathrm{cm}^{2}\right]$ for PECVDnitride films on the response surface, which predicts a minimum in the lower right corner.

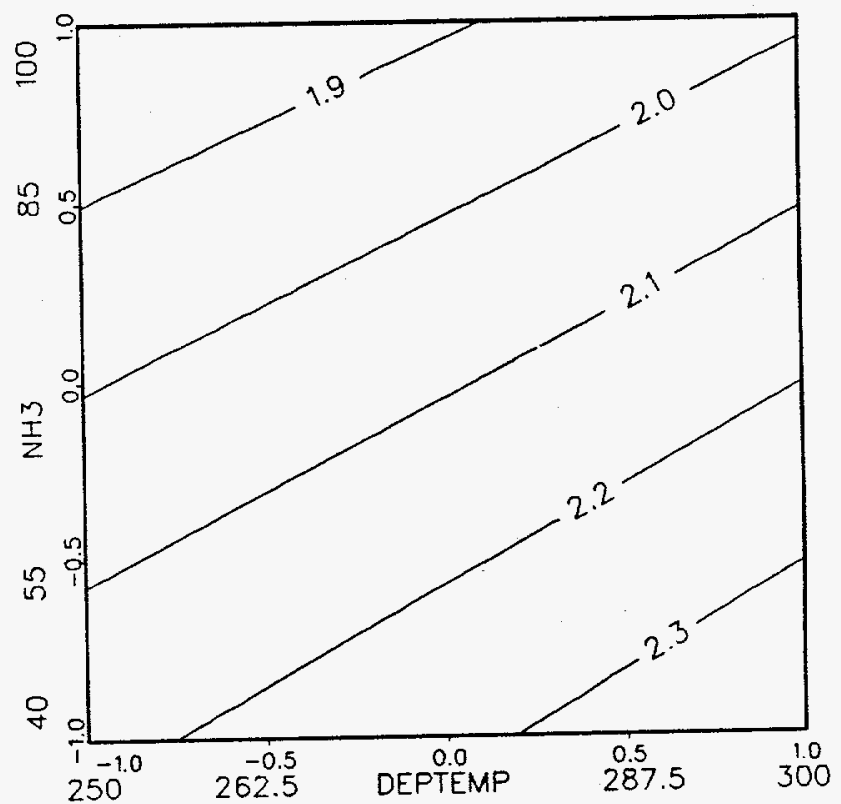

Figure 6. Contours of constant refractive index for PECVD-nitride films on the response surface, which predicts a maximum in the lower right corner.

\section{Solar Cell Fabrication}

The analysis predicted that the optimized nitride conditions should produce a film with surface passivation properties almost as good as that of our best thermal oxides, while at the same time producing optimal ARC properties. We tested this prediction by fabricating solar 
cells on float-zone wafers and also on cast mc-Si wafers provided by Solarex Corp. Figure 8 shows measured internal quantum efficiency curves for the same surface conditions of Figure 7, where the optimized curve here represents measured IOE data on a cell fabricated using the predicted best deposition conditions.

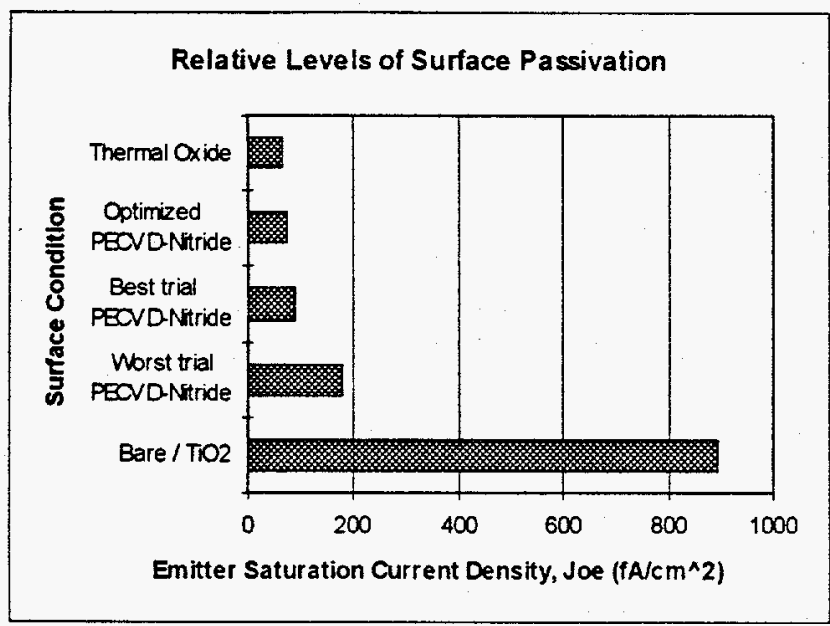

Figure 7 . The measured and predicted $J_{o e}$ values for the nitride quadratic experiment.

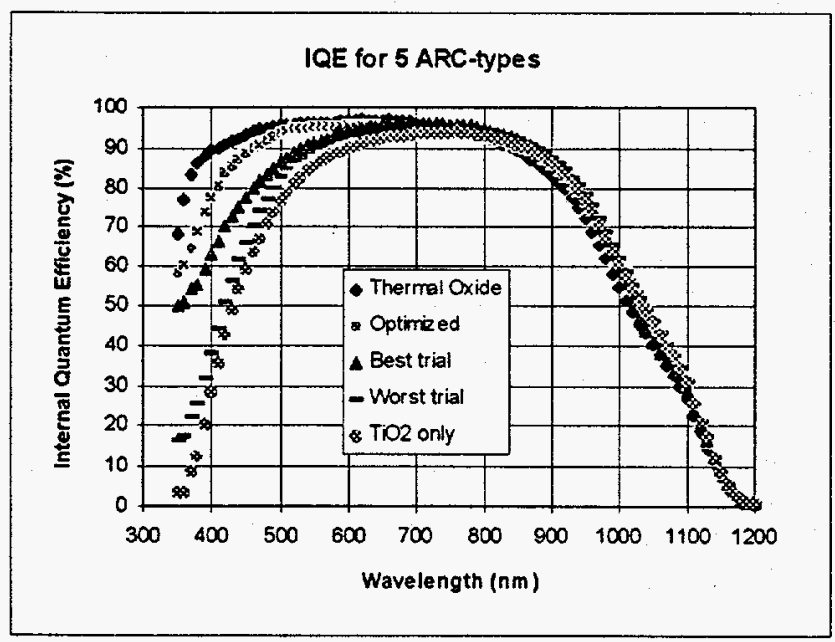

Figure 8. Measured IQE curves on mc-Si cells for the same five surface conditions shown in Fig. 7 .

Figure 8 shows a continuous improvement in the blue response of nitride-passivated cells as the deposition conditions approach those of the optimized case. This is entirely consistent with the lower $J_{\text {oe }}$ values measured earlier and proves that the conditions predicted to be optimized do indeed result in better-passivated emitters, even on mc-Si cells. Also, there is no degradation in red response from the plasma, and future work will determine if the addition of hydrogen results in long-wavelength improvement.
Finally, Figure 9 shows the measured short-circuit current densities of the mc-Si and float-zone Si cells fabricated using the same surface conditions as in Fig. 7.

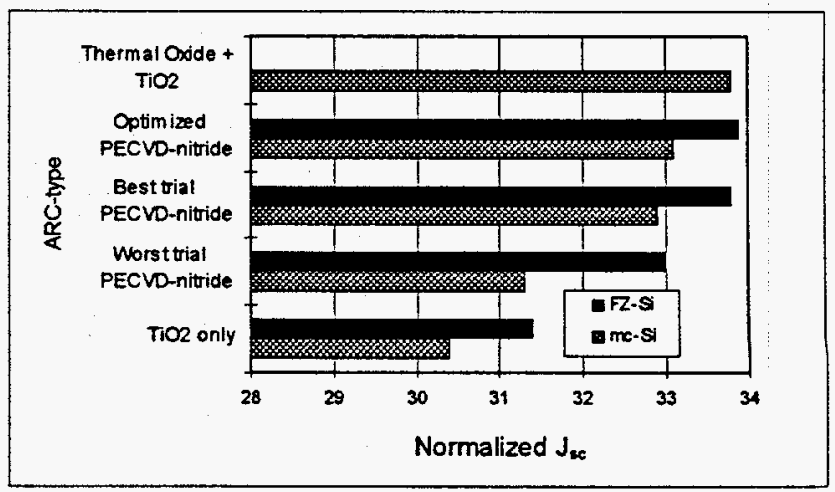

Figure 9. Measured short-circuit current densities, normalized to the same reflectance, for the surface conditions of Figs. 7 and 8, for mc-Si and FZ-Si cells.

\section{CONCLUSIONS}

The choice of deposition and anneal conditions had a large impact on the quality of PECVD emitter passivations. A set of conditions was found which provides excellent surface passivation and optimum ARC properties from a single-layer nitride film, resulting in a $9 \%$ increase in current and $2 \%$ increase in open-circuit voltage compared to a $\mathrm{TiO}_{2}$ layer.

\section{ACKNOWLEDGEMENTS}

The authors would like to thank K. Wroblewski for much of the PECVD equipment characterization that was done, and for performing the main-effects depositions. Many thanks go to B.L. Silva, M.E. Buck and J.W. Tingley for the cell and wafer processing. We are also grateful to $L$. Irwin and J.K. Snyder for the many cell measurements.

\section{REFERENCES}

[1] Z. Chen, P. Sana, J. Salami, and A. Rohatgi, "A Novel and Effective PECVD $\mathrm{SiO}_{2} / \mathrm{SiN}$ Antireflection Coating for Si Solar Cells," IEEE Trans. Elect. Dev., 40, June 1993, pp. 1161-1165.

[2] J. Szlufcik et al., Improvement in mc-Si Solar Cells after Thermal Treatment of PECVD Silicon Nitride AR Coating," Proc. 12th European PV Solar Energy Conf., 1994, pp. 1018-1021.

[3] D. S. Ruby and J. D. Levine, Low-Temperature Emitter-Passivation for Silicon Solar Cells," Proc. 11th European PV Solar Energy Conf., 1992, pp. 385-388.

[4] P.A. Basore and B.R. Hansen, Microwave-Detected Photoconductance Decay," 21st IEEE PVSC, 1990, pp. 374-379. 